\title{
SOLUSI TERHADAP PERMASALAHAN INTERNAL DAN EKSTERNAL PADA SEKSI PENDIDIKAN DINIYAH DAN PONDOK PESANTREN DI KANTOR KEMENTERIAN AGAMA KABUPATEN MOJOKERTO
}

\author{
Nur Rokhmad, Elma Abadiyah, Emilinia Indah Permatasari, \\ Ni'matus Sholihah \\ UIN Sunan Ampel, Surabaya - Indonesia |
}

\begin{abstract}
Abstrak: Penelitian ini bertujuan untuk mengetahui dan mendeskripsikan mengenai solusi terhadap permasalahan internal maupun eksternal pada seksi PD Pontren di Kantor Kemenag Kabupaten Mojokerto. Metode penelitian yang digunakan adalah penelitian kualitatif deskriptif. Teknik pengumpulan data menggunakan wawancara, observasi dan dokumentasi dengan informan yaitu kepala seksi dan pegawai seksi PD Pontren. Hasil penelitian menunjukkan bahwa permasalahan internal yang terjadi pada seksi PD Pontren yaitu kemampuan IT pegawai yang tergolong kurang. Hal ini disebabkan karena tidak tersedianya bimbingan atau pelatihan bagi pegawai dalam bidang IT. Solusi dari permasalahan tersebut yaitu dengan cara autodidak mengenai beberapa pekerjaan kantor khususnya yang berhubungan dengan IT. Sedangkan permasalahan eksternal antara lain kurangnya tingkat kesadaran pengurus lembaga seperti pondok pesantren, madrasah diniyah dan TPQ atas pentingnya EMIS bagi legalitas lembaga; kurangnya tingkat time management pengurus lembaga dalam menghadiri acara yang diadakan oleh seksi PD Pontren. Hal tersebut disebabkan oleh kurangnya rasa ketergantungan antara pihak lembaga dengan seksi PD Pontren dan kurangnya pengetahuan terhadap sistem birokrasi.Solusi dari permasalahan tersebut yaitu dengan membentuk forum komunikasi antara seksi PD Pontren dengan pengurus lembaga.
\end{abstract}

Keywords: Solusi, Permasalahan, Faktor Penyebab

\section{Pemdahuluan \\ Dalam kehidupan, manusia sering kali dihadapkan oleh masalah. Berbagai macam masalah hadir tanpa diundang ke}


kehidupan kita. Mulai dari masalah pribadi, masalah keluarga, sampai masalah lembaga atau organisasi. Ketiga masalah ini tentu sudah tidak asing bagi kita, karena hampir semua orang menjumpainya. Berbicara mengenai masalah, tidak akan terlepas dari pengertian masalah itu sendiri. Meskipun manusia selalu berhadapan dengan masalah, akan tetapi tidak sedikit manusia yang tidak memahami definisi masalah itu sendiri. Lantas, apa sih sebenarnya masalah itu?

Seperti yang telah tercantum dalam kamus besar bahsa indonesia, yakni masalah adalah sesuatu yang harus dipecahkan atau diselesaikan.

Notoadmojo mendefinisikan jika masalah yakni merupakan suatu kesenjangan antara apa yang seharusnya terjadi dengan apa yang sudah terjadi tentang suatu hal atau kesenjangan antara kenyataan yang terjadi dengan yang seharusnya terjadi serta harapan dan kenyataannya dari masalah tersebut.

Hudojo masalah adalah salah satu bentuk pertanyaan kepada seseorang yang dimana orang tersebut tidak mempunyai hukum yang bisa digunakan dengan segera untuk menemukan jawaban dari pertanyaan (masalah) tersebut. Sedangkan Dorothy Craig mendefinisikan masalah merupakan situasi yang akan datang yang tidak diharapkan.

Menurut Irmasyah Effendi, masalah adalah pelajaran ketika Anda sadar sebagai kesadaran jiwa, Anda dapat melihat dengan mudah berbagai kelemahan dan masalah dalam hidup Anda. Sedangkan menurut Abdul Cholil, masalah adalah bagian kecil dari kehidupan. Setiap manusia pasti pernah memiliki dan menghadapi masalah baik yang berasal dari diri sendiri maupun yang bersumber dari orang lain.

Jadi kesimpulannya adalah masalah merupakan sesuatu yang belum ditemukan cara penyesaiannya atau jawabannya, yang menjadi teka-teki yang menuntut pemecahan (penelitian) ilmiah, karena untuk menemukan jawabannya hanya mungkin didapatkan melalui penelitian atau cara kerja ilmiah.

Masalah secara umum dapat dikelompokkan menjadi dua jenis yaitu masalah sederhana dan masalah rumit/kompleks. Perbedaan 
di antara kedua jenis masalah ini yaitu jika masalah sederhana memiliki skala yang kecil, tidak terpaut dengan masalah lainnya, tidak memiliki konsekuensi yang besar, pemecahannya tidak terlalu rumit, dan dapat dipecahkan oleh individu. Jangkauan masalah ini hanya sebatas pada individu saja dan dapat diselesaikan oleh individu pula. Maka masalah rumit/kompleks memiliki cakupan skala yang lebih besar, dapat terkait dengan berbagai masalah lainnya, memiliki konsekuensi yang sangat besar, dan penyelesaiannya membutuhkan kerja sama kelompok serta analisis yang mendalam. Jangkauan masalah ini berkaitan dengan banyak individu dan hanya dapat diselesaikan oleh banyak individu pula.

Faktor timbulnya masalah terbagi menjadi dua, faktor internal dan faktor eksternal. Pada faktor internal, permasalahan yang timbul berasal dari dalam, baik dalam diri sendiri ataupun dalam organisasi. Sedangkan faktor eksternal sebaliknya, penyebab timbulnya masalah berasal dari luar. Misalnya dalam lembaga atau organisasi, masalah yang timbul akibat faktor dari internal adalah bullying dan pelecehan, job description yang tidak jelas, senioritas, kurangnya kesempatan berkembang yang sama, dan pergantian kebijakan. Sedangkan masalah yang timbul dari faktor eksternal misalnya salah pengertian antara pihak luar organisasi dengan pihak dalam organisasi atas suatu hal.

Masalah memang sering kali dikaitkan dengan kesialan dan juga bencana. Padahal, jika dikaji lebih mendalam lagi mengenai hakekat dasar dari masalah, masalah sebenarnya tidak melulu menghasilkan dampak negatif. Terkadang masalah hadir sebagai bentuk peluang untuk memperbaiki berbagai kelemahan yang ada dalam diri sendiri atau organisasi. Hal tentu ini bergantung dengan bagaimana kita dalam mencari solusi. Pemilihan solusi penyelesaian merupakan tindakan untuk menyelesaikan atau proses yang menggunakan kekuatan berfikir untuk menyelaraskan permasalahan yang akan dikaitkan dengan konsep pemahaman materi.

Pemilihan solusi adalah suatu kegiatan kognitif yang kompleks dengan melibatkan suatu proses dan strategi (Hudiono, 2007). Artinya salah satu kemampuan yang diharus dimiliki siswa adalah 
strategi dalam melakukan pemilihan solusi. Dalam pemilihan solusi penyelesaian siswa harus memiliki 1 kemampuan untuk membaca, memahami, transformasi, keterampilan proses, dan penulisan (Newman dalam White, 2005)

(Mayer dalam Kirkley, 2003) mendefinisikan pemilihan solusi sebagai suatu proses banyak langkah siswa dengan menemukan hubungan antara pengalaman (skema) dan pengetahuan masa lalunya dengan masalah yang sekarang dihadapinya dan kemudian bertindak untuk menyelesaikannya. Disini merupakan penekanan dari bekal pengetahuan yang sudah didapat akan diuji kembali pemilihan solusi penyelesaian pesesrta didik dalam menyelesaikan permasalahan yang sedang dihadapi.

Hudiono (2007) berpendapat bahwa pemilihan solusi adalah suatu aktivitas kognitif yang kompleks dengan melibatkan suatu proses dan strategi. Kegiatan - kegiatan yang diklasifikasikan sebagai pemilihan solusi dalam matematika diantaranya menyelesaikan soal persamaan kuadrat, yakni mencari persamaan kuadrat baru yang akan diperoleh setelah melakukan proses atau pemilihan solusi penyelesaian, yang juga merupakan metode penemuan solusi melalui tahap demi tahap pemilihan solusi. Pengertian solusi adalah jalan keluar atau jawaban dari suatu masalah.

(Munif Chatib : 2011) Solusi adalah cara atau jalan yang digunakan untuk memecahkan atau menyelesaikan masalah tanpa adanya tekanan. Maksud tanpa adanya tekanan adalah adanya objektivitas dalam menentukan pemecahan masalah dimana orang yang yang mencari solusi tidak memaksakan pendapat pribadinya dan berpedoman pada kaidah atau aturan yang ada. Jika tidak demikian maka solusi yang didapat akan sangat subjektif sehingga dikhawatirkan bukan solusi yang tepat. Sehingga masalah-masalah yang ada tidak akan terselesaikan dengan baik. Dan masalahmasalah yang ada hanyak akan bersifat negatif saja.

Untuk mendapatkan solusi yang tepat atas suatu permasalahan ada beberapa tahapan yang harus dilalui. Pertama kita perlu mengenali apa sebenarnya masalah yang terjadi. Kemudia kita cari fakta atau bukti mengenai permasalahan tersebut. Setelah itu kita 
telaah apa yang melatarbelakangi munculnya masalah tersebut. Setelah jelas masalah beserta latar belakangnya barulah kita dapat mempertimbangkan berbagai kemungkinan solusi yang dapat digunakan untuk memecahkan masalah tersebut. Dari sekian banyak alternatif solusi kita pilih salah satu solusi yang dianggap paling tepat. Kemudian kita jalankan solusi yang terpilih. Setelah itu kita evaluasi hasilnya apakah solusi yang kita pilih sudah tepat untuk memecahkan masalah yang dihadapi, jika belum maka siklus pemecahan masalah kita ulangi kembali.

Dalam hal ini tidak terkecuali pada seksi PD Pontren di Kantor Kementrian Agama Kabupaten Mojokerto. Masalah-masalah yang ada tidak dapat dihindari, baik masalah dari faktor internal maupun masalah dari faktor eksternal. Untuk itu kepala seksi PD Pontren dan seluruh staf di Kantor Kemeterian Agama Kabupaten Mojokerto hanya dapat mencari solusi yang tepat untuk permasalahan yang ada. Sehingga diharapkan melalui solusi yang tepat masalah yang ada cepat terselesaikan dengan baik atau setidaknya meminimalisir terjadinya masalah tersebut agar tidak terulang kembali.

\section{Metodologi}

Metode penelitian yang digunakan adalah kualitatif deskriptif. Menurut Arikunto, penelitian deskriptif merupakan penelitian mengumpulkan data berdasarkan faktor-faktor yang menjadi pendukung terhadap objek penelitian, kemudian menganalisa faktor-faktor tersebut untuk dicari peranannya. Menurut Poerwandari, penelitian kualitatif adalah penelitian yang menghasilkan dan mengolah data yang sifatnya deskriptif, seperti transkripsi wawancara, catatan lapangan, gambar, foto, rekaman video, dan lain-lain. Metode pendekatan deskriptif kualitatif merupakan metode pengolahan data dengan cara menganalisa faktor-faktor yang berkaitan dengan objek penelitian dengan penyajian data secara lebih mendalam terhadap objek penelitian. Penelitian kualitatif merupakan penelitian yang bersifat deskriptif dan cenderung menggunakan analisis data. 
Waktu penelitian dilaksanakan pada 31 Agustus 2020 S/d 08 Oktober 2020. Lokasi penelitian yaitu Kantor Kementerian Agama Kabupaten Mojokerto yang beralamatkan di JL. R.A. Basuni 28 A Kecamatan Sooko Kabupaten Mojokerto Provinsi Jawa Timur. Subjek penelitian adalah peneliti sendiri yang menjadi instrumen utama dalam penelitian kualitatif, sedangkan informan dan partisipan dapat dari peneliti sendiri maupun pihak lain yang dilibatkan dalam penelitian. Subjek penelitian pada penelitian ini adalah peneliti yang merupakan mahasiswa program studi manajemen pendidikan Islam yang melaksanakan praktik manajemen pendidikan Islam di Kantor Kementerian Agama Kabupaten Mojokerto. Informan pada penelitian ini yaitu kepala seksi dan pegawai seksi pendidikan diniyah dan pondok pesantren Kementerian Agama Kabupaten Mojokerto.

Teknik pengumpulan data menggunakan beberapa cara yaitu dengan melakukan wawancara, pengamatan atau observasi terhadap pelaksanaan kerja kantor dan partisipasi pengurus lembaga pada acara yang diadakan seksi pendidikan diniyah dan pondok pesantren serta melalui teknik dokumentasi. Wawancara adalah metode pengambilan data dengan cara menanyakan sesuatu kepada seseorang yang menjadi informan atau responden. Menurut Nawawi dan Martini, observasi adalah pengamatan dan pencatatan secara sistemik terhadap unsur-unsur yang tampak dalam suatu gejala atau gejala-gejala dalam objek penelitian. Observasi dibutuhkan untuk memahami proses terjadinya wawancara dan hasil wawancara dapat dipahami dalam konteksnya.

Teknik analisis data dilakukan dengan beberapa cara yaitu reduksi data, penyajian data serta penarikan kesimpulan. Reduksi data adalah bentuk analisis yang menggolongkan, mengarahkan, merangkum, memfokuskan pada hal-hal yang penting, membuang yang tidak perlu dan mengorganisasikan data sehingga kesimpulan akhir dapat diambil. Penyajian data merupakan kegiatan menyusun informasi, sehingga memberi kemungkinan adanya penarikan kesimpulan. Bentuk penyajian data kualitatif berupa teks naratif yaitu berbentuk catatan lapangan. Penarikan kesimpulan adalah hasil analisis yang dapat digunakan unuk mengambil tindakan. 


\section{Hasil dan Pembahasan}

Salah satu seksi yang ada di Kantor Kementerian Agama Kabupaten Mojokerto yaitu seksi pendidikan diniyah dan pondok pesantren atau yang dapat disebut dengan seksi PD Pontren. Seksi PD Pontren mengurusi beberapa lembaga seperti pondok pesantren, madrasah diniyah dan taman pendidikan Al-Qur'an. Pengurusan tersebut dengan cara memberikan layanan seperti bimbingan, pembinaan, pengeluarkan ijin operasional, perpanjangan ijin operasional, penerbitan rekomendasi pengajuan rekomendasi pengajuan bantuan baik pondok pesantren, madrasah diniyah dan taman pendidikan Al-Qur'an, legalisir ijazah dan SKHUN Wajar DIKDAS dan Paket C serta penerbitan rekomendasi izin belajar santri ke luar negeri.

Pada seksi tersebut terdiri dari satu orang kepala seksi dan empat orang pelaksana atau pegawai. Keempat pegawai tersebut dibagi menjadi beberapa bidang tanggungjawab, seperti ada yang menjadi penanggungjawab dalam bidang terkait pondok pesantren, penanggungjawab madrasah diniyah, penanggungjawab taman pendidikan Al-Qur'an serta sebagai operator EMIS dan IJOP. Sistem informasi manajemen yang ada pada seksi PD Pontren antara lain EMIS (Education Management Information System), IJOP (Izin Operasional), SIKAP (Sistem Informasi Ketenagaan Pesantren) dan arsip surat yang dilaksanakan secara manual.

EMIS (Education Management Information System) merupakan sebuah sistem informasi manajemen pendidikan yang mengatur data dan informasi pendidikan untuk disimpan, dikelola, dianalisis dan digunakan dalam pengambilan keputusan pendidikan, dalam hal ini mencakup lembaga pondok pesantren, madrasah diniyah dan taman pendidikan Al-Qur'an. Ketiga lembaga tersebut diwajibkan untuk terdaftar pada EMIS dan mengupdate setiap enam bulan sekali. Namun pada kenyataannya tidak semua lembaga tersebut mengupdate EMIS.

IJOP (Izin Operasional) merupakan sebuah sistem informasi yang dijadikan sebagai sistem pelayanan pendaftaran dan perpanjangan ijin operasional secara online melalui alamat resmi yaitu https://ditpdpontren.kemenag.go.id/. Tujuan dari IJOP yaitu 
untuk meningkatkan akuntabilitas dan transparansi dalam pelaksanaan pengajuan, perpanjangan dan pencabutan perijinan operasional pesantren di Kementeria Agama RI. Terdapat beberapa prosedur pengurusan IJOP pondok pesantren antara lain tahap registrasi, tahap verifikasi dokumen, tahap visitasi, tahap rekomendasi Kabupaten/Kota, tahap rekomendasi Provinsi, tahap penerbitan NSPP dan SK, serta tahap penerbitan piagam. Pada tahap registrasi, pondok pesantren mendaftarkan lembaganya dan mengupload dokumen. Selanjutnya pada tahap verifikasi dokumen yaitu Kemenag Kab/Kota melakukan verifikasi kelengkapan dokumen yang telah diupload. Pada tahap visitasi, Kemenag $\mathrm{Kab} /$ Kota melakukan visitasi dan pengecekan dokumen dan upload hasil visitasi. Selanjutnya tahap rekomendasi Kab/Kota yang dilakukan oleh Kemenag Kab/Kota yang akan menguploas surat rekomendasi jika sudah disetujui. Tahap rekomendasi Provinsi, Kemenag Provinsi akan upload surat rekomendasi jika sudah disetujui. Pada tahap penerbitan NSPP dan SK, hasil verifikasi dilihat oleh Direktorat dan selanjutnya diterbitkannya NSPP dan SK. Dan yang terakhir yaitu tahap penerbitan Piagam Ijin Operasional yang dilakukan oleh Kemenag Kab/Kota.

Beberapa layanan yang ada pada seksi PD Pontren yaitu pengajuan perijinan operasional lembaga baik pondok pesantren, madrasah diniyah dan taman pendidikan Al-Qur'an, pengajuan perpanjangan perijinan operasional lembaga, penerbitan rekomendasi pengajuan bantuan pada lembaga, legalisir ijazah dan SKHUN Wajar DIKDAS dan Paket C serta penerbitan rekomendasi izin belajar santri ke luar negeri. Karena pada seksi PD Pontren terdapat beberapa layanan tersebut dan mengharusnya seksi PD Pontren berinteraksi dengan masyarakat khususnya pengurus lembaga seperti pondok pesantren, madrasah diniyah dan taman pendidikan Al-Qur'an, maka terdapat beberapa permasalahan utama yang ada di PD Pontren Kabupaten Mojokerto yang terjadi selama tiga tahun kepengurusan Bapak Drs. Nur Rokhmad, MM sebagai Kepala Seksi PD Pontren.

Permasalahan pertama, timbul dari internal PD Pontren itu sendiri dan yang kedua timbul dari pihak eksternal PD Pontren. 
Permasalahan internal yang terjadi pada seksi PD Pontren yaitu kemampuan IT beberapa pegawai yang tergolong kurang. Hal ini disebabkan karena tidak tersedianya bimbingan atau pelatihan bagi pegawai dalam bidang IT. Dan untuk permasalahan ekternal yakni dari ketiga lembaga tersebut tidak semuanya memiliki EMIS (Education Management Information System), tidak meng-update EMIS yang sudah dimiliki atau disamakan seperti tahun-tahun sebelumnya dan dari sisi image lembaga, malas mengoperasikan EMIS.

Tentu hal ini sangat berpengaruh, karena EMIS sendiri menyediakan data lapangan yang berasal dari ketiga lembaga tersebut baik pondok pesantren, madrasah diniyah, maupun taman pendidikan al-qur'an. Yang mana kementerian agama dapat menggunakan data EMIS sebagai data awal dan data lapangan yang bisa digunakan sebagai dasar pengambilan keputusan. Penggunaan data EMIS dalam pengambilan keputusan di lingkungan kemenag sudah sampai $80 \%$. Akan tetapi dalam beberapa pengambilan keputusan yang sensitif seperti penentuan-penentuan calon sertifikat maupun pemberian bantuan, kemenag perlu untuk mengadakan verifikasi dan melakukan pemberkasan secara biasa atau manual. Apabila kebijakan yang diambil hanya berdasarkan data EMIS maka dapat dikhawatirkan akan terjadi kesalah pahaman, karena data EMIS memiliki jangka waktu pengisian sehingga data yang ada di dalamnya tidak selalu up to date dan merupakan data yang valid, reliabel, time line dan dapat selalu diakses oleh pengguna yang membutuhkan baik dalam setiap pengambilan keputusan, penelitian, maupun kebutuhan lain yang membutuhkan data lembaga.

Adanya EMIS dirasa sangat cukup membantu proses pengambilan keputusan maupun dapat mempercepat kinerja kemenag. Peran data dalam pengambilan keputusan merupakan hal yang sangat penting. Karena dengan adanya data yang valid, akurat, dan mudah untuk diakses akan menentukan kebijakan yang diambil oleh seorang pengambil keputusan. Terutama pada saat akan menerima bantuan, maka lembaga yang memiliki EMIS dan meng-updatenya yang akan diutamakan. 
Selain itu, permasalahan yang muncul dari faktor eksternal PD Pontren adalah rendahnya kesadaran dari perwakilan-perwakilan lembaga yang sudah ditunjuk untuk hadir dalam acara-acara yang sudah diadakan dari pihak Kemenag. Hal ini sesuai dengan yang disampaikan oleh bapak Zamroni, selaku operator ruangan di PD Pontren. Seperti dalam acara "Sosialisasi dan Pengambilan Dokumen Bantuan Pembelajaran Daring" misalnya, masih banyak dari perwakilan-perwakilan yang sudah ditunjuk datang terlambat sehingga mengakibatkan mundurnya jadwal acara yang sudah ditetapkan. Hal terkait masalah internal ini juga sesuai wawancara dengan kepala seksi PD Pontren Bapak Drs. Nur Rokhmad, MM.

Yang menjadi pekerjaan rumah saya sejak menjabat sebagai Kasi PD Pontren tahun 2017 lalu yaitu mengadakan mobile connection tiap kecamatan dalam rangka untuk pendataan emis agar pihak PD Pontren mengetahui setiap lembaga yang ada di wilayah Kabupaten Mojokerto, dengan harapan lembaga yang sebelumnya belum tertata dalam bidang emis-nya jadi lebih tertata maksimal. Namun langkah tersebut mendapat respon yang masif, dan akhirnya dapat tuntas selama 6 bulan. Pekerjaan rumah lainnya bagi saya yaitu responsibily lembaga terhadap emis, pihak lembaga masih mengajukan pertanyaan yang terkesan klasik yakni mengapa mereka harus mengoperasikan emis bagi lembaganya, apakah akan mendapatkan bantuan untuk lembaganya. Padahal suatu lembaga yang terdaftar pada emis tidak sebatas karena itu saja, melainkan sebagai bentuk legalitas lembaga agar dapat melangsungkan pembinaan dari pemerintah. Masing-masing lembaga tersebut memiliki karakteristik tersendiri. Pondok Pesantren memiliki karakteristik yang berbeda dari Madin dan TPQ/LPQ yaitu terletak pada cara mendidik para santrinya. Pondok pesantren menyiapkan santrinya agar menjadi lulusan yang mampu menjalankan segalanya. Para santri diawasi betul di pesantren selama 24 jam. Dalam mendidik santri dan menyelenggarakan kegiatan pada pondok pesantren perlu adanya perpaduan antara program kemenag dan program dari pondok pesantren. Nilai kebersamaan yang ada di pondok pesantren lebih ketara debandingkan lembaga lainnya, baik dalam kegiatan formal maupun non formal. Selain itu, 
kekuatan spiritual santri lebih kuat karena hasil dari bimbingan dan didikan yang terkontrol. Hal ini salah satu yang mengakibatkan suatu permasalahan yang terjadi antara pihak PD Pontren Kemenag Kab. Mojokerto dan pihak pengelola pondok pesantren, yakni ketika terdapat suatu kumpulan untuk membahas suatu permasalahan, terjadi keterlambatan dalam menngikuti kegiatan tersebut. Keterlambatan tersebut dirasa kurang wajar oleh Bapak Nur Rokhmad karena berlangsung lebih dari 1 jam. Bentuk penyelesaian mengenai permasalahan dengan pihak pondok pesantren tersebut yaitu dengan membangun komunikasi, kebersamaan, integritas untuk mengetahui kebutuhan dari pihak pondok pesantren."

"Lembaga yang kedua yaitu madrasah diniyah yang selanjutnya disebut madin. Proses pendidikan pada madin tidak berlangsung selama 24 jam seperti pondok pesantren, pada madin hanya berlangsung selama 3-5 jam. Ilmu dan skill yang didapatkan oleh para santri lebih terbatas dibandingkan dengan santri pondok pesantren. Pada madin terdapat beberapa tingkatan yaitu Ula setingkat MI, Wustha setingkat dengan MTs, dan Ulya setingkat dengan MA. Dari masing-masing tingkatan atau jenjang pada madin tersebut terdapat perbedaan dalam pemberian materi kepada santri. Pada jenjang Ula, ustadz/ah-nya lebih berpengaruh, pada jenjang MTs ustadz/ah-nya 50\% untuk mewarnai karakter santri dan santri memiliki kreativitas, sedangkan pada jenjang Ulya campur tangan ustadz/ah hanya $25 \%$ dan sisanya merupakan peran santri tersendiri. Ketika terdapat suatu kumpulan ataupun rapat dengan pihak kemenag, pihak madin lebih respon dalam menindak lanjuti undangan kegiatan tersebut. Pihak madin lebih tepat waktu dalam menghadiri acara tersebut."

“Lembaga yang ketiga yaitu Taman Pendidikan Al-Qur'an atau disingkat menjadi TPQ. TPQ biasanya merupakan lembaga yang dimiliki oleh masyarakat. Terdapat 3 model lembaga pendidikan Al-Qur'an yaitu TKQ, TPQ dan TQA. TQA merupakan lembaga yang menangani santri kalangan mahasiswa. Pada lembaga TPQ, santrinya dididik oleh masyarakat dengan budaya semi kota yang diharapkan dapat menjadi lulusan yang tepat waktu, lebih kreatif, 
inovatif yang dipengaruhi juga oleh didikan dari keluarga. Dari ketiga lembaga tersebut, permasalahan yang dominan yaitu ketidaktepatan waktu dalam mengikuti acara yang diadakan oleh pihak PD Pontren Kemenag Kab. Mojokerto. Hal tersebut dikarenakan belum adanya rasa butuh atau ketergantungan dengan pihak PD Pontren Kemenag Kab. Mojokerto dan rendahnya pengetahuan terhadap birokrasi."

Dari permasalahan-permasalahan yang ada, solusi yang yang ditempuh dari PD Pontren dalam usaha menyelesaikan masalah yang ada yakni :

\section{permasalahan internal}

- Berusaha saling membantu dalam mejalankan tugas yang ada, terutama yang berhubungan dengan IT. Jika pegawai yang satu bisa, pegawai tersebut akan membantu pegawai yang lainnya.

- Belajar mandiri.

permasalahan eksternal

- Memberikan sosialisasi pemahaman tentang pentingnya EMIS.

- Diadakan pembimbingan dan pelatihan mengenai cara pengoperasian EMIS kepada operator masing-masing lembaga. Baik pondok pesantren, madrasah diniyah dan taman pendidikan Al-Qur'an.

- Membangun komunikasi yang baik antara pihak PD Pontren dengan lembaga-lembaga pondok pesantren, madrasah diniyah dan taman pendidikan Al-Qur'an melalui forum komunikasi yang sudah dibuat, dalam hal ini melalui grub Whatsapp.

- Membangun kebersamaan melalui agenda rutin yakni silaturahim setiap satu bulan sekali bersama anggota korcam sekabupaten Mojokerto. (Dilaksankan sebelum wabah corona ada)

Solusi- solusi masalah eksternal yang ada sesuai dengan wawancara bersama Bapak Nur Rokhmad. "Solusi yang saya ambil oleh untuk menyelesaikan permasalahan tersebut yaitu dengan membentuk forum yang terdiri dari FKPP (Forum Komunikasi Pondok Pesantren), FKDT (Forum Komunikasi Diniyah dan Takmiliyah), dan FKPQ (Forum Komunikasi Pendidikan AlQur'an). Dari forum tersebut muncul rasa kebersamaan dan saling 
sharing untuk membantu dalam mengkomunikasikan suatu permasalahan yang terjadi pada suatu lembaga dan memberikan pemahaman kepada pimpinan lembaga. Selain itu juga sebagai media untuk menginformasikan apabila ada suatu undangan kegiatan pembinaan yang diadakan oleh pihak kemenag dan bantuan yang diberikan. Dulu sebelum ada corona ada agenda silaturahim dengan perwakilan korcam setiap satu bulan sekali, tetapi untuk saat ini harus ditiadakan karena tidak memungkinkan dilaksanakan"

Solusi yang ada terkait masalah ekternal juga diberikan oleh staf PD Pontren yang bertindak sebagai operator ruangan, bapak Zamroni, S.Pd.I. "Ya untuk prihal EMIS dari pihak kita melakukan sosialisasi pentingnya EMIS. Tidak hanya itu, kita juga mengadakan pelatihan bagaimana pengoperasian EMIS untuk operator-operator lembaga masing-masing."

Sedangkan untuk solusi permasalahan internal ini sesuai dengan wawancara kami bersama ibu Umi Fadilah, SE selaku bendahara atau pengelola keuangan di PD Pontren di Kemenag Kab. Mojokerto. "Selama ini belum ada pelatihan khusus. Jadi untuk menyesuaikan dengan penempatan bidang dalam hal IT kami saling membantu antara staf satu dengan staf yang lain, dan juga belajar sendiri sebisanya."

\section{Kesimpulan}

Seksi PD Pontren di Kantor Kementerian Kabupaten Mojokerto mengurusi beberapa lembaga seperti pondok pesantren, madrasah diniyah dan taman pendidikan Al-Qur'an. Pengurusan tersebut dengan cara memberikan layanan seperti bimbingan, pembinaan, pengeluarkan ijin operasional, perpanjangan ijin operasional, penerbitan rekomendasi pengajuan rekomendasi pengajuan bantuan baik pondok pesantren, madrasah diniyah dan taman pendidikan Al-Qur'an, legalisir ijazah dan SKHUN Wajar DIKDAS dan Paket $C$ serta penerbitan rekomendasi izin belajar santri ke luar negeri. Dalam menjalankan tugasnya tidak luput dari adanya permasalahan yang timbul didalamnya. Baik dari faktor internal maupun eksternal. Permasalahan-permasalahan yang ada seperti 
permasalahan internal yang terjadi pada seksi PD Pontren yaitu kemampuan IT beberapa pegawai yang tergolong kurang. Hal ini disebabkan karena tidak tersedianya bimbingan atau pelatihan bagi pegawai dalam bidang IT. Permasalahan ekternal dari ketiga lembaga tersebut tidak semuanya memiliki EMIS (Education Management Information System), tidak meng-update EMIS yang sudah dimiliki atau disamakan seperti tahun-tahun sebelumnya dan dari sisi image lembaga, malas mengoperasikan EMIS.

\section{References}

Afifuddin dan Beni Ahmad Saebani, Metodologi Penelitian Kualitatif (Bandung: CV. Pustaka Setia, 2012), 130.

Wikipedia. "Penelitian Kualitatif".diakses pada 13 Oktober 2020 di https://id.wikipedia.org/wiki/Penelitian_kualitatif.

Direktorat Pendidikan Diniyah dan Pondok Pesantren, Direktorat Pendidikan Islam, Kementerian Agama Republik Indonesia, "Prosedur Izin Oprasional Pondok Pesantren." Di akses pada 13 Oktober $2020 \quad$ https://ditpdpontren.kemenag. go.id/ijoppesantren/login,

Google. "Pengertian menurut para ahli" diakses pada 13 Oktober 2020

di

https://www.pengertianmenurutparaahli.net/pengertiansolusi/. 